\title{
Kausalitas Kebijakan Moneter Konvensional dengan Inflasi dan Pertumbuhan Ekonomi di Indonesia Periode Q1 2008 - Q4 2020
}

\author{
Rahmad Abdul Gani*, Ima Amaliah \\ Prodi Ilmu Ekonomi dan Bisnis, Fakultas Ekonomi dan Bisnis, Universitas \\ Islam Bandung, Indonesia. \\ *ganirahmad22@gmail.com, imaamaliah@unisba.ac.id
}

\begin{abstract}
This study aims to identify the causality of conventional monetary policy with inflation and economic growth in Indonesia during the observation period. The research method used is descriptive quantitative. The data used are data from the first quarter of 2008 to the fourth quarter of 2020 . This study uses secondary data published by BI, OJK, BPS, World Bank, as well as various literatures that will be used. The data analysis method used in this study is the VECM and Grangger Causality model consisting of the Grangger test, IRF test, VD test, and VECM estimation. The results of this study found that, causally, there is no continuity of conventional monetary policy transmission lines. In terms of IRF, the shock given by conventional variables to the inflation response subsided and remained stable for longer. In this case, the conventional variable is inflationary. In VD, conventional variables tend to give a larger negative contribution to inflation and reduce output. According to VECM, conventional variables in the short term tend to have a positive impact on inflation, and provide trade-offs in the long term.
\end{abstract}

Keywords: Conventional Monetary Policy, VECM, IRF Test, FEVD Test..

\begin{abstract}
Abstrak. Penelitian ini bertujuan untuk mengidentifikasi kausalitas kebijakan moneter konvensional dengan inflasi dan pertumbuhan ekonomi Indonesia selama periode pengamatan. Metode penelitian yang digunakan adalah deskriptif kuantitatif. Data yang digunakan adalah data kuartal I 2008 sampai kuartal IV 2020. Penelitian ini menggunakan data sekunder yang dipublikasikan BI, OJK, BPS, World Bank, serta berbagai literatur yang akan digunakan. Metode analisis data yang digunakan dalam penelitian ini adalah model VECM dan Grangger Causality terdiri dari uji grangger, uji IRF, uji VD, dan estimasi VECM. Hasil penelitian ini menemukan bahwa, secara kausalitas tidak terdapat kesinambungan alur transmisi kebijakan moneter konvensional. Secara IRF, shock yang diberikan oleh variabel konvensional terhadap respon inflasi mereda dan stabil lebih lama. Dalam hal ini, variabel konvensional bersifat inflationer. Secara VD, variabel konvensional cendrung memberikan kontribusi negatif lebih besar terhadap inflasi dan menurunkan output. Secara VECM, variabel konvensional dalam jangka pendek cenderung memberikan dampak positif terhadap inflasi, dan memberikan trade-off dalam jangka panjang.
\end{abstract}

Kata Kunci: Kebijakan Moneter Konvensional, VECM, Uji IRF, dan Uji FEVD. 


\section{A. Pendahuluan}

Kebijakan moneter digunakan oleh otoritas moneter untuk mengontrol kuantitas uang dalam perekonomian. Kuantitas uang yang ditawarkan dapat mempengaruhi tingkat output, tingkat bunga dan tingkat pengangguran, dan tingkat harga keseluruhan (Case dan Fair, 2006). Kebijakan moneter dapat mempengaruhi kegiatan ekonomi riil dan harga melalui suatu mekanisme jalur transmisi kebijakan moneter (JTKM), yang merupakan tahapan-tahapan dilalui oleh instrumen kebijakan untuk sampai ke sasaran akhir kebijakan moneter. Mekanisme tersebut dapat bekerja melalui berbagai saluran salah satunya suku bunga (Warjiyo dan Agung, 2002). Dalam proses perputaran uang yang dilakukan dengan mekanisme transmisi kebijakan moneter maka melibatkan peran perbankan, karena perbankan adalah sektor yang pertama kali yang merasakan efek kebijakan moneter untuk ditransferkan ke sektor riil. Di sisi lain, karena bank menjalankan fungsi intermediasi dalam menghimpun dana (simpanan dan deposito) dan menyalurkannya kredit dan pembiayaan kepada dunia usaha. Terciptanya stabilitas moneter dan sistem perbankan menjadi kondisi ideal yang diharapkan dalam pelaksanaan kebijakan moneter. Stabilitas moneter dicerminkan oleh terkendalinya inflasi, nilai tukar, suku bunga, dan besaran moneter seperti jumlah uang beredar. Sedangkan stabilnya sistem perbankan dapat dicerminkan dengan kondisi perbankan yang sehat dan berjalannya fungsi intermediasi perbankan dalam memobilisasi simpanan masyarakat untuk disalurkan dalam bentuk kredit dan pembiayan lain kepada dunia usaha (Warjiyo, 2006).

Bank Indonesia sebagai otoritas moneter di Indonesia menggunakan Operasi Pasar Terbuka (OPT) sebagai instrumen moneter untuk mencapai kondisi ideal. Dalam pelaksanaan OPT, terdapat beberapa instrumen sering digunakan sebagai acuan pasar uang konvensional meliputi BI rate (sejak 2016 resmi diganti menjadi BI 7-Day RR) dan suku bunga Sertifikat Bank Indonesia (RSBI). BI rate merupakan suatu instrumen pengendalian suku bunga yang digunakan Bank Indonesia untuk mencapai sasaran kebijakan moneter, baik sasaran awal, maupun sasaran antara dan sasaran akhir. Adanya instrument tersebut bertujuan agar transmisi kebijakan moneter dapat mencapai sasaran akhir yakni terciptanya tingkat harga yang diinginkan (tingkat inflasi) dan pertumbuhan ekonomi (Khoirul, 2009).

Mengacu pada teori, ketika BI rate ditingkatkan, tingkat suku bunga SBI akan meningkat maka perbankan akan membeli obligasi tersebut sehingga likuiditas perbankan berkurang dan bank secara otomatis akan mengurangi pinjaman kepada masyarakat dengan meningkatkan suku bunga pinjaman (Kemu \& Ika, 2016). Dengan begitu, permintaan uang akan konsumsi dan investasi oleh masyarakat menurun sehingga peredaran uang di masyarakat berkurang yang mampu menekan gejolak inflasi. Namun, fakta dilapangan, seringkali ditemukan ketidaksesuaian antara transmisi dan hasil sasaran akhir moneter dalam melaksanakan kebijakan moneter konvensional. Hal ini tercermin dari gambar 1 dan 2.

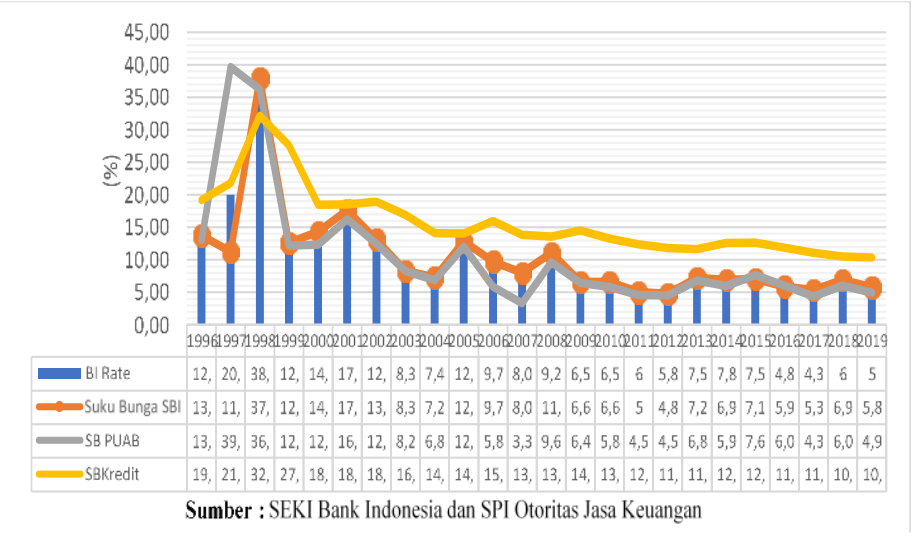

Gambar 1. Data Deskriptif Suku Bunga Perbankan dan Moneter di Indonesia 


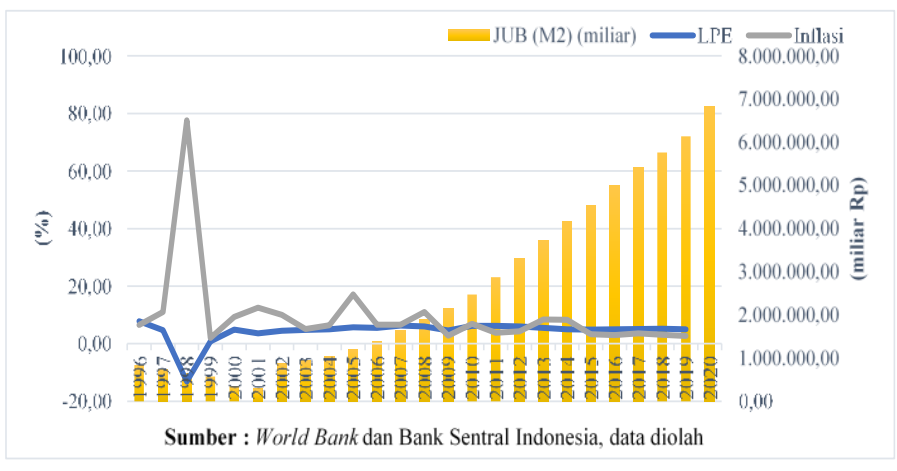

Gambar 2. Data Besaran Moneter dan Sasaran Akhir Kebijakan Moneter Indonesia

Saat based money diterapkan dalam kerangka kebijakan moneter di tahun 1996 sampai pertengahan tahun 2005, BI lebih dominan melakukan pendekatan kuantitas sebagai sasaran operasional yang didasarkan pada hipotesis bahwa pengendalian besaran-besaran moneter secara efektif dapat mengendalikan stabilitas perekonomian. Namun, saat terjadi krisis tahun 1996-1998 justru laju pertumbuhan ekonomi menunjukkan trend yang menurun hingga menyentuh diangka minus $13,13 \%$ dan diiringi oleh tingkat inflasi yang tinggi sebesar 77,63\%. $\mathrm{Hal}$ ini mengindikasikan bahwa pengendalian besaran moneter dalam implementasi kebijakan moneter secara langsung memunculkan terjadnya inflasi dan justru menurunkan pertumbuhan ekonomi.

Balik dari pengalaman tersebut, Bank Indonesia akhirnya merubah kerangka kebijakan moneter dari based money menjadi inflation targeting framework (ITF) pada juli 2005. Perbedaan penerapan pada ITF dengan menggunakan suku bunga sebagai sasaran operasional. Penerapan kerangka ini didasarkan pada hipotesis bahwa pengendalian tingkat harga melalui suku bunga secara efektif dapat mengendalikan stabilitas perekonomian. Namun, fakta dilapangan menunjukkan hal yang berbeda. Pengendalian harga melalui suku bunga justru menimbulkan inflasi. Akhir tahun 2005, terjadi kenaikan suku bunga acuan BI rate sebesar 4,6\%, kenaikan tersebut direspon oleh suku bunga SBI dan Pasar Uang Antrbank Konvensional (PUAB), tetapi tidak dengan suku bunga kredit yang mengalami penurunan sebesar 2 persen lebih kecil dari tahu sebelumnya. Ketidaksesuaian ini pada gilirannya mengakibatkan sasaran akhir moneter juga tidak sesuai dengan yang diinginkan dimana pertumbuhan ekonomi tumbuh sebesar 0,6\% diwaktu yang bersamaan inflasi meningkat sebesar 5\% jauh lebih besar dari tahun sebelumnya. Hal yang serupa juga kembali terjadi di tahun 2008.

Mengamati perkembangan penelitian yang telah dilakukan sebelumnya, penulis memandang penting untuk dilakukan penelitian lanjutan mengingat perbankan konven telah mengalami perkembangan yang sangat pesat dibandingkan dengan data-data yang digunakan para peneliti sebelumnya. Oleh karena itu, penulis fokus untuk menyelidiki bagaimana kausalitas kebijakan moneter konvensional dengan inflasi dan pertumbuhan ekonomi di Indonesia periode Q1 2008 - Q4 2020. Selanjutnya, tujuan dalam penelitian ini diuraikan dalam pokok-pokok sbb.

1. Untuk mengetahui hubungan kausalitas antara kebijakan moneter konvensional dengan inflasi dan pertumbuhan ekonomi di Indonesia Periode Q1 2008 sampai Q4 2020.

2. Untuk mengetahui tinkgat respon inflasi dan pertumbuhan ekonomi terhadap shock kebijakan moneter konvensional di Indonesia, periode Q1 2008 sampai Q4 2020.

3. Untuk mengetahui besar komposisi kebijakan moneter konvensional terhadap inflasi dan pertumbuhan ekonomi di Indonesia, periode Q1 2008 sampai Q4 2020.

4. Untuk mengetahui pegaruh kebijakan moneter konvensional terhadap inflasi dan pertumbuhane ekonomi di Indonesia dalam jangka pendek dan jangka panjang, periode Q1 2008 sampai Q4 2020. 


\section{B. Metodelogi}

Metode penelitian yang digunakan dalam penelitian ini adalah deskriptif kuantitatif. Data yang digunakan adalah data kuartal I 2008 sampai kuartal IV 2020. Penelitian ini menggunakan data sekunder yang dipublikasikan BI, OJK, BPS, World Bank, serta berbagai literatur yang akan digunakan. Metode analisis data yang digunakan dalam penelitian ini adalah model VECM dan Grangger Causality terdiri dari uji grangger, uji IRF, uji VD, estimasi VECM.

\section{Hasil dan Pembahasan}

\section{Uji Kausalitas Grangger}

Tabel 1. Uji Kausalitas Grangger

\begin{tabular}{|c|c|c|c|c|c|c|c|}
\hline Null Hypothesis: & obs & F-Statistic & Prob. & $\begin{array}{l}\text { LPE does not Granger Cause RSBI } \\
\text { RSBI does not Granger Cause LPE }\end{array}$ & 50 & $\begin{array}{l}0.94784 \\
0.28828\end{array}$ & $\begin{array}{l}0.3952 \\
0.7509 \\
\end{array}$ \\
\hline $\begin{array}{l}\text { RSBI does not Granger Cause BIRATE } \\
\text { BIRATE does not Granger Cause RSBI }\end{array}$ & 50 & $\begin{array}{l}1.50704 \\
4.49406\end{array}$ & $\begin{array}{l}0.2325 \\
0.0166\end{array}$ & $\begin{array}{l}\text { RKREDIT does not Granger Cause RPUAB } \\
\text { RPUAB does not Gran qer Cause RKREDIT } \\
\end{array}$ & 50 & $\begin{array}{l}1.85222 \\
7.71981 \\
\end{array}$ & $\begin{array}{l}0.1687 \\
0.0013 \\
\end{array}$ \\
\hline \multirow{2}{*}{$\begin{array}{l}\text { RPUAB does not Granger Cause BIRATE } \\
\text { BIRATE does not Granger Cause RPUAB }\end{array}$} & \multirow[t]{2}{*}{50} & \multirow{2}{*}{$\begin{array}{l}1.50587 \\
5.07410\end{array}$} & \multirow{2}{*}{$\begin{array}{l}0.2328 \\
0.0103\end{array}$} & $\begin{array}{l}\text { KYD does not Granger Cause RPUAB } \\
\text { RPUAB does not Granger Cause KYD }\end{array}$ & 50 & $\begin{array}{l}0.94800 \\
2.43767\end{array}$ & $\begin{array}{l}0.3951 \\
0.0988 \\
\end{array}$ \\
\hline & & & & $\begin{array}{l}\text { JUB does not Granger Cause RPUAB } \\
\text { RPUAB does not Granger Cause JUB }\end{array}$ & 50 & $\begin{array}{l}1.91390 \\
1.52187\end{array}$ & $\begin{array}{l}0.1593 \\
0.2293\end{array}$ \\
\hline $\begin{array}{l}\text { RKREDIT does not Granger Cause BIRATE } \\
\text { BIRATE does not Granger Cause RKREDIT }\end{array}$ & 50 & $\begin{array}{l}1.42232 \\
12.8111\end{array}$ & $\begin{array}{r}0.2518 \\
4 . \mathrm{E}-05 \\
\end{array}$ & $\begin{array}{l}\text { INF does not Granaer Cause RPUAB } \\
\text { RPUAB does not Granger Cause INF }\end{array}$ & 50 & $\begin{array}{l}7.63824 \\
0.67812 \\
\end{array}$ & $\begin{array}{l}0.0014 \\
0.5127 \\
\end{array}$ \\
\hline $\begin{array}{l}\text { KYD does not Granger Cause BIRATE } \\
\text { BIRATE does not Granger Cause KYD }\end{array}$ & 50 & $\begin{array}{l}1.78656 \\
1.03722\end{array}$ & $\begin{array}{l}0.1792 \\
0.3628 \\
\end{array}$ & $\begin{array}{l}\text { LPE does not Granger Cause RPUAB } \\
\text { RPUAB does not Granger Cause LPE } \\
\end{array}$ & 50 & $\begin{array}{l}1.31282 \\
0.14688 \\
\end{array}$ & $\begin{array}{l}0.2792 \\
0.8638 \\
\end{array}$ \\
\hline $\begin{array}{l}\text { JUB does not Granger Cause BIRATE } \\
\text { BIRATE does not Granger Cause JUB }\end{array}$ & 50 & $\begin{array}{l}3.23847 \\
0.19067\end{array}$ & $\begin{array}{l}0.0485 \\
0.8271\end{array}$ & $\begin{array}{l}\text { KYD does not Granger Cause RKREDIT } \\
\text { RKREDIT does not Granger Cause KYD } \\
\end{array}$ & 50 & $\begin{array}{l}3.74721 \\
0.61951 \\
\end{array}$ & $\begin{array}{l}0.0312 \\
0.5427 \\
\end{array}$ \\
\hline \multirow{2}{*}{$\begin{array}{l}\text { INF does not Granger Cause BIRATE } \\
\text { BIRATE does not Granger Cause INF } \\
\end{array}$} & \multirow[t]{2}{*}{50} & \multirow{2}{*}{$\begin{array}{l}1.33366 \\
3.02419 \\
\end{array}$} & \multirow{2}{*}{$\begin{array}{l}0.2737 \\
0.0586\end{array}$} & $\begin{array}{l}\text { JUB does not Granger Cause RKREDIT } \\
\text { RKREDIT does not Granger Cause JUB } \\
\end{array}$ & 50 & $\begin{array}{l}4.67585 \\
1.51332\end{array}$ & $\begin{array}{l}0.0143 \\
0.2312 \\
\end{array}$ \\
\hline & & & & $\begin{array}{l}\text { INF does not Granger Cause RKREDIT } \\
\text { RKREDIT does not Granger Cause INF } \\
\end{array}$ & 50 & $\begin{array}{l}14.2829 \\
0.21709 \\
\end{array}$ & $\begin{array}{l}2 . E-05 \\
0.8057 \\
\end{array}$ \\
\hline $\begin{array}{l}\text { LPE does not Granger Cause BIRATE } \\
\text { BIRATE does not Granger Cause LPE }\end{array}$ & 50 & $\begin{array}{l}0.83371 \\
0.50557\end{array}$ & $\begin{array}{l}0.4410 \\
0.6065\end{array}$ & $\begin{array}{l}\text { LPE does not Granger Cause RKREDIT } \\
\text { RKREDIT does not Granaer Cause LPE }\end{array}$ & 50 & $\begin{array}{l}0.70325 \\
2.01127 \\
\end{array}$ & $\begin{array}{l}0.5003 \\
0.1457 \\
\end{array}$ \\
\hline $\begin{array}{l}\text { RPUAB does not Granger Cause RSBI } \\
\text { RSBI does not Granger Cause RPUAB }\end{array}$ & 50 & $\begin{array}{l}1.35574 \\
5.19451\end{array}$ & $\begin{array}{l}0.2681 \\
0.0093\end{array}$ & $\begin{array}{l}\text { JUB does not Granger Cause KYD } \\
\text { KYD does not Granger Cause JUB }\end{array}$ & 5 & $\begin{array}{l}15.7118 \\
1.20177 \\
\end{array}$ & $\begin{array}{l}\text { 7.E- }-06 \\
0.3101 \\
\end{array}$ \\
\hline $\begin{array}{l}\text { RKREDIT does not Granger Cause RSBI } \\
\text { RSBI does not Granger Cause RKREDIT }\end{array}$ & 50 & $\begin{array}{l}1.12115 \\
4.04597\end{array}$ & $\begin{array}{l}0.3348 \\
0.0242\end{array}$ & $\begin{array}{l}\text { INF does not Granger Cause KYD } \\
\text { KYD does not Granger Cause INF } \\
\end{array}$ & 50 & $\begin{array}{l}0.34645 \\
1.46296 \\
\end{array}$ & $\begin{array}{l}0.7091 \\
0.2424 \\
\end{array}$ \\
\hline KYD does not Granger Cause RSBI & 50 & 0.92515 & 0.4039 & $\begin{array}{l}\text { LPE does not Granger Cause KYD } \\
\text { KYD does not Granger Cause LPE }\end{array}$ & 50 & $\begin{array}{l}9.51379 \\
2.26244 \\
\end{array}$ & $\begin{array}{l}0.0004 \\
0.1158 \\
\end{array}$ \\
\hline RSBI does not Granger Cause KYD & & 2.88022 & 0.0665 & $\begin{array}{l}\text { INF does not Granaer Cause JUB } \\
\text { JUB does not Granger Cause INF }\end{array}$ & 50 & $\begin{array}{l}0.11293 \\
1.58816 \\
\end{array}$ & $\begin{array}{l}0.8935 \\
0.2155 \\
\end{array}$ \\
\hline $\begin{array}{l}\text { JUB does not Granger Cause RSBI } \\
\text { RSBI does not Granger Cause JUB }\end{array}$ & 50 & $\begin{array}{l}2.22549 \\
0.61150\end{array}$ & $\begin{array}{l}0.1198 \\
0.5470 \\
\end{array}$ & $\begin{array}{l}\text { LPE does not Granger Cause JUB } \\
\text { JUB does not Granger Cause LPE } \\
\end{array}$ & 50 & $\begin{array}{l}2.49606 \\
8.02664 \\
\end{array}$ & $\begin{array}{l}0.0938 \\
0.0010 \\
\end{array}$ \\
\hline $\begin{array}{l}\text { INF does not Granger Cause RSBI } \\
\text { RSBI does not Granger Cause INF }\end{array}$ & 50 & $\begin{array}{l}2.30827 \\
2.28945\end{array}$ & $\begin{array}{l}0.1111 \\
0.1130\end{array}$ & $\begin{array}{l}\text { LPE does not Granger Cause INF } \\
\text { INF does not Granger Cause LPE }\end{array}$ & 50 & $\begin{array}{l}1.19611 \\
0.05524 \\
\end{array}$ & $\begin{array}{l}0.3118 \\
0.9463 \\
\end{array}$ \\
\hline
\end{tabular}

Dalam model output, variabel konvensional meliput suku bunga (BI rate, SBI, PUAB, dan kredit) tidak terdapat hubungan kausalitas/sebab-akibat dua arah secara langsung terhadap output. Artinya, variabel konvensional (BI rate, SBI, PUAB, dan kredit) tidak mampu menjelaskan perubahan pada tingkat pertumbuhan output. Begitu sebaliknya. Namun, terdapat hubungan kausalitas satu arah antara pertumbuhan ekonomi dengan penyaluran kredit. Jika terdapat perubahan pada pertumbuhan ekonomi maka akan menyebabkan perubahan pada penyaluran kredit, dan tidak berlaku sebaliknya. Sedangkan dalam model inflasi, hasil uji kausalitas mengindikasikanbeberap bahwa variabel moneter konvensional meliputi BI rate dan suku bunga SBI tidak terdapat hubungan kausalitas/sebab-akibat dua arah terhadap tingkat inflasi. Tetapi, terdapat hubungan kausalitas satu arah antara tingkat inflasi terhadap suku bunga PUAB dan kredit sehingga, saat terjadi perubahan tingkat inflasi, maka mengakibatkan terjadinya perubahan pada tingkat suku bunga PUAB dan kredit.

\section{Uji Impuls Response Function (IRF Test)}

Secara keseluruhan, alur transmisi kebijakan moneter konvensional dalam model inflasi menunjukkan hasil variabel moneter konvensional (RSBI, RPUAB, dan RKREDIT) memberikan dampak inflationer terhadap inflasi dan bersifat permanen. Kecuali, suku bunga kebijakan moneter/BI Rate dan penyaluran kredit (KYD). Namun, shock penyaluran kredit mengakibatkan respon/dampak positif dalam pengertian meningkatkan pertumbuhan output/LPE dan bersifat melemah seiring bertambahnya/berjalannya periode. Kemudian, laju 
pertumbuhan ekonomi/output berdampak inflationer terhadap tingkat inflasi. Shock variabelvariabel Konvensional terhadap inflasi mereda dan stabil jauh lebih lama. Hal ini sesuai dengan kajian empiris Ascarya (2012). Sedangkan dalam model output variabel suku bunga (RSBI, RPUAB, dan RKREDIT) cenderung memberikan respon negatif dalam pengertian menghambat pertumbuhan output.

Tabel 2. Impuls Response Function Test

\begin{tabular}{|c|c|c|c|c|c|c|c|c|}
\hline \multicolumn{9}{|c|}{ Response of INF: } \\
\hline Perio... & BIRATE & RSBI & RPUAB & RKREDIT & KYD & JUB & INF & LPE \\
\hline 1 & 0.454731 & -0.228196 & -0.389846 & -0.032001 & 0.292306 & 0.086736 & 0.878188 & 0.000000 \\
\hline 2 & 0.541574 & -0.084035 & -0.831688 & -0.278905 & 0.683551 & 0.117902 & 0.717813 & -0.132868 \\
\hline 3 & 0.419786 & -0.381889 & -0.623868 & -0.711109 & 0.624806 & 0.215530 & 0.880582 & -0.017490 \\
\hline 4 & 0.350642 & -0.247627 & -0.730619 & -0.920107 & 0.528370 & 0.100957 & 0.867129 & -0.317008 \\
\hline 5 & 0.034387 & -0.460541 & -0.678762 & -0.672354 & 0.688909 & 0.289190 & 0.640129 & -0.048795 \\
\hline 6 & 0.075437 & -0.344173 & -0.733308 & -0.756282 & 0.493971 & 0.083248 & 0.702456 & 0.079410 \\
\hline 7 & 0.163269 & -0.271787 & -0.534089 & -0.649381 & 0.423768 & 0.222753 & 0.585211 & -0.185588 \\
\hline 8 & 0.144249 & -0.329637 & -0.570008 & -0.537287 & 0.446278 & 0.229997 & 0.669061 & -0.075410 \\
\hline 9 & 0.242421 & -0.227080 & -0.641403 & -0.565812 & 0.464528 & 0.214285 & 0.659560 & -0.164451 \\
\hline 10 & 0.239595 & -0.252503 & -0.578766 & -0.593628 & 0.410806 & 0.283520 & 0.657089 & -0.199872 \\
\hline 11 & 0.264233 & -0.249883 & -0.597841 & -0.632027 & 0.410894 & 0.283479 & 0.702997 & -0.252316 \\
\hline 12 & 0.228600 & -0.243898 & -0.608015 & -0.613957 & 0.442291 & 0.321460 & 0.655256 & -0.237039 \\
\hline 13 & 0.233973 & -0.240208 & -0.605501 & -0.645984 & 0.404956 & 0.310065 & 0.671079 & -0.235339 \\
\hline 14 & 0.235622 & -0.221563 & -0.580397 & -0.643218 & 0.372775 & 0.341654 & 0.648979 & -0.300584 \\
\hline 15 & 0.221212 & -0.233911 & -0.574412 & -0.613233 & 0.378155 & 0.370507 & 0.648038 & -0.288862 \\
\hline \multicolumn{9}{|c|}{ Response of LPE: } \\
\hline Perio... & BIRATE & RSBI & RPUAB & RKREDIT & KYD & JUB & INF & LPE \\
\hline 1 & -0.163379 & -0.056848 & -0.336337 & 0.068980 & 0.658691 & -0.372609 & -0.049179 & 0.941528 \\
\hline 2 & 0.094709 & 0.120392 & -0.367245 & -0.366254 & 0.391257 & -0.932400 & -0.036695 & 1.110355 \\
\hline 3 & 0.108615 & -0.106629 & -0.216434 & -0.421198 & 0.249852 & -0.821255 & -0.007309 & 0.775348 \\
\hline 4 & -0.025311 & -0.291273 & -0.381457 & -0.285657 & 0.382395 & -0.817284 & -0.007929 & 1.042949 \\
\hline 5 & 0.114350 & -0.209095 & -0.399369 & -0.368163 & 0.402878 & -0.949949 & -0.050533 & 1.173078 \\
\hline 6 & 0.252388 & -0.182863 & -0.273772 & -0.465688 & 0.254124 & -1.026425 & -0.034056 & 1.057476 \\
\hline 7 & 0.287547 & -0.269385 & -0.310481 & -0.438290 & 0.293733 & -1.030000 & 0.007040 & 1.017738 \\
\hline 8 & 0.294311 & -0.290278 & -0.406380 & -0.456438 & 0.328726 & -1.065586 & -0.013596 & 1.124474 \\
\hline 9 & 0.385580 & -0.282098 & -0.366384 & -0.561662 & 0.254815 & -1.102487 & -0.005919 & 1.092625 \\
\hline 10 & 0.427661 & -0.301792 & -0.327414 & -0.592570 & 0.220153 & -1.101354 & -0.001750 & 1.036202 \\
\hline 11 & 0.442176 & -0.327537 & -0.366089 & -0.589040 & 0.248083 & -1.113438 & -0.002978 & 1.067642 \\
\hline 12 & 0.480080 & -0.314162 & -0.379191 & -0.634194 & 0.203683 & -1.134263 & -0.016792 & 1.061457 \\
\hline 13 & 0.522640 & -0.321814 & -0.339946 & -0.666388 & 0.148342 & -1.115645 & -0.018040 & 1.002684 \\
\hline 14 & 0.546005 & -0.326414 & -0.340433 & -0.666927 & 0.137629 & -1.103562 & -0.019005 & 0.986339 \\
\hline 15 & 0.578005 & -0.315060 & -0.349783 & -0.681600 & 0.123363 & -1.101386 & -0.027826 & 0.975989 \\
\hline
\end{tabular}

\section{Uji Varian Dekomposisi (Uji VD)}

Sumbangan variabel konvensional kredit yang disalurkan (KYD) merupakan variabel penyumbang positif terbesar terhadap variabel LPE sebesar $26 \%$ pada periode pertama. Namun pada periode 15, kontribusi variabel konvensional KYD terhadap LPE sebesar 3,59\% jauh lebih kecil di banding periode pertama, atau mengalami penurunan sumbangan positif sebesar $22,41 \%$ dari periode pertama. Sehingga dapat dikatakan bahwa kontribusi positif KYD bersifat melemah seiring bertambahnya periode.

Kontribusi positif yang diberikan oleh KYD terhadap LPE masih lebih kecil disbanding kontribusi negatif variabel konvensional lainnya (RSBI, RPUAB, dan RKREDIT) terhadap LPE sebesar $17,31 \%$. Hal ini akan menghambat terciptanya pertumbuhan ekonomi. Pada model inflasi, kontribusi positif penyaluran kredit (KYD) dalam pengertian menahan inflasi sebesar $13,13 \%$ dan bersifat menguat mulai dari awal periode hingga akhir. Meski demikian, kontribusi negatif yang diberikan oleh variabel konvensional lainnya (RSBI, RPUAB, dan RKREDIT) jauh lebih besar yakni $48,14 \%$ dibanding kontribusi positifnya. Secara keseluruhan, variabel konvensional memberikan kontribusi negatif yang lebih besar dibandingkan kontribusi positifnya terhadap LPE dan Inflasi. Hasil analisis ini sejalan/sesuai dengan kajian empiris Ascarya (2012). 
Tabel 3. Uji Varian Dekomposisi

\begin{tabular}{|c|c|c|c|c|c|c|c|c|c|}
\hline \multicolumn{10}{|c|}{ Variance Decomposition of INF: } \\
\hline Perio... & S.E. & BIRATE & RSBI & RPUAB & RKREDIT & KYD & JUB & INF & LPE \\
\hline 1 & 1.129619 & 16.20488 & 4.080875 & 11.91030 & 0.080253 & 6.695957 & 0.589573 & 60.43816 & 0.000000 \\
\hline 2 & 1.833016 & 14.88366 & 1.760009 & 25.11007 & 2.345629 & 16.44920 & 0.637629 & 38.28838 & 0.525424 \\
\hline 3 & 2.406130 & 11.68163 & 3.540473 & 21.29553 & 10.09571 & 16.28938 & 1.172430 & 35.61463 & 0.310216 \\
\hline 4 & 2.914774 & 9.407511 & 3.134374 & 20.79473 & 16.84440 & 14.38625 & 0.918910 & 33.11958 & 1.394249 \\
\hline 5 & 3.254587 & 7.556744 & 4.516390 & 21.02858 & 17.77837 & 16.01948 & 1.526580 & 30.43307 & 1.140779 \\
\hline 6 & 3.546389 & 6.409594 & 4.745584 & 21.98606 & 19.52080 & 15.43186 & 1.340800 & 29.55439 & 1.010912 \\
\hline 7 & 3.740382 & 5.952509 & 4.794082 & 21.80350 & 20.56260 & 15.15622 & 1.559991 & 29.01613 & 1.154959 \\
\hline 8 & 3.929237 & 5.528831 & 5.048120 & 21.86242 & 20.50327 & 15.02431 & 1.756269 & 29.19334 & 1.083436 \\
\hline 9 & 4.123657 & 5.365381 & 4.886573 & 22.26885 & 20.49818 & 14.90999 & 1.864598 & 29.06371 & 1.142722 \\
\hline 10 & 4.305105 & 5.232373 & 4.827348 & 22.23859 & 20.70805 & 14.59020 & 2.144445 & 28.99502 & 1.263971 \\
\hline 11 & 4.497791 & 5.138789 & 4.731255 & 22.14074 & 20.94636 & 14.20145 & 2.361875 & 29.00685 & 1.472689 \\
\hline 12 & 4.676858 & 4.991731 & 4.647854 & 22.16789 & 21.09641 & 14.02913 & 2.656913 & 28.79112 & 1.618956 \\
\hline 13 & 4.851312 & 4.871781 & 4.564752 & 22.16003 & 21.37949 & 13.73507 & 2.877757 & 28.67118 & 1.739938 \\
\hline 14 & 5.015740 & 4.778279 & 4.465504 & 22.06993 & 21.64528 & 13.40166 & 3.156154 & 28.49632 & 1.986867 \\
\hline 15 & 5.172134 & 4.676606 & 4.404065 & 21.98882 & 21.76182 & 13.13801 & 3.481331 & 28.36891 & 2.180444 \\
\hline \multicolumn{10}{|c|}{ Variance Decomposition of LPE: } \\
\hline Perio... & SE & BIRATE & RSBI & RPUAB & RKREDIT & KYD & JUB & INF & LPE \\
\hline 1 & 1.268625 & 1.658534 & 0.200802 & 7.028841 & 0.295650 & 26.95857 & 8.626596 & 0.150276 & 55.08073 \\
\hline 2 & 2.039258 & 0.857566 & 0.426251 & 5.963390 & 3.340095 & 14.11436 & 24.24406 & 0.090538 & 50.96374 \\
\hline 3 & 2.396684 & 0.826236 & 0.506532 & 5.132849 & 5.506666 & 11.30521 & 29.29385 & 0.066477 & 47.36218 \\
\hline 4 & 2.821111 & 0.604378 & 1.431594 & 5.532904 & 4.999681 & 9.996744 & 29.53534 & 0.048769 & 47.85060 \\
\hline 5 & 3.279312 & 0.568877 & 1.466042 & 5.577902 & 4.960553 & 8.907647 & 30.24975 & 0.059838 & 48.20940 \\
\hline 6 & 3.657921 & 0.933277 & 1.428177 & 5.043146 & 5.607594 & 7.641762 & 32.18571 & 0.056760 & 47.10357 \\
\hline 7 & 4.000894 & 1.296667 & 1.647164 & 4.817787 & 5.887466 & 6.926755 & 33.53171 & 0.047755 & 45.84470 \\
\hline 8 & 4.365738 & 1.543459 & 1.825453 & 4.912649 & 6.037622 & 6.384353 & 34.11887 & 0.041077 & 45.13651 \\
\hline 9 & 4.712950 & 1.993754 & 1.924664 & 4.819815 & 6.601036 & 5.770635 & 34.74905 & 0.035405 & 44.10564 \\
\hline 10 & 5.027860 & 2.475318 & 2.051407 & 4.659024 & 7.189080 & 5.262135 & 35.33079 & 0.031121 & 43.00112 \\
\hline 11 & 5.338944 & 2.881193 & 2.195678 & 4.602086 & 7.592962 & 4.882699 & 35.68283 & 0.027631 & 42.13492 \\
\hline 12 & 5.642206 & 3.303778 & 2.276026 & 4.572334 & 8.062086 & 4.502244 & 35.99146 & 0.025627 & 41.26645 \\
\hline 13 & 5.919731 & 3.780742 & 2.363154 & 4.483444 & 8.591097 & 4.152792 & 36.24771 & 0.024209 & 40.35685 \\
\hline 14 & 6.182118 & 4.246663 & 2.445594 & 4.414180 & 9.041121 & 3.857322 & 36.42262 & 0.023142 & 39.54935 \\
\hline 15 & 6.435873 & 4.724970 & 2.496192 & 4.368336 & 9.463843 & 3.595885 & 36.53572 & 0.023223 & 38.79184 \\
\hline
\end{tabular}

\section{Estimasi VECM}

Tabel 4. Hasil Estimasi VECM Jangka Pendek

\begin{tabular}{|c|c|c|c|c|c|c|}
\hline \multirow{2}{*}{ Error Correction: } & \multicolumn{3}{|c|}{$\mathrm{D}(\mathrm{INF})$} & \multicolumn{3}{|c|}{$\mathrm{D}(\mathrm{LPE})$} \\
\hline & \multicolumn{3}{|c|}{ koefisienStandar Error T Hitung/T-Stat } & koefisien & \begin{tabular}{|l|} 
Standar Error \\
\end{tabular} & T Hitung/T-Stat \\
\hline CointEq1 & -0.170999 & $(0.05026)$ & {$[-3.40221]$} & 0.018740 & $(0.05645)$ & [0.33199] \\
\hline $\mathrm{D}(\mathbb{I N F}(-1))$ & -0.019525 & $(0.15451)$ & {$[-0.12637]$} & 0.005517 & $(0.17352)$ & {$[0.03180]$} \\
\hline $\mathrm{D}(\operatorname{INF}(-2))$ & 0.507401 & $(0.17701)$ & [2.86644] & -0.025657 & $(0.19880)$ & {$[-0.12906]$} \\
\hline D(BIRATE(-1)) & 0.544656 & $(0.59953)$ & {$[0.90846]$} & 0.187116 & $(0.67331)$ & {$[0.27790]$} \\
\hline D(BIRATE(-2)) & -0.629982 & $(0.66674)$ & {$[-0.94487]$} & -0.185626 & $(0.74878)$ & {$[-0.24790]$} \\
\hline $\mathrm{D}(\mathrm{RSBI}(-1))$ & 0.225053 & $(0.48552)$ & {$[0.46353]$} & 0.241105 & $(0.54527)$ & {$[0.44218]$} \\
\hline $\mathrm{D}(\mathrm{RSBI}(-2))$ & $|-0.407646|$ & $(0.53048)$ & {$[-0.76844]$} & -0.196864 & $(0.59576)$ & {$[-0.33044]$} \\
\hline $\mathrm{D}(\mathrm{RPUAB}(-1))$ & -0.788894 & $(0.34269)$ & {$[-2.30207]$} & 0.117697 & $(0.38486)$ & {$[0.30582]$} \\
\hline D(RPUAB(-2)) & 0.472060 & $(0.37684)$ & {$[1.25267]$} & -0.301878 & $(0.42322)$ & {$[-0.71330]$} \\
\hline D(RKREDIT(-1)) & -2673495 & $(1.22127)$ & {$[-2.18912]$} & -0.297552 & $(1.37155)$ & {$[-0.21695]$} \\
\hline D(RKREDIT(-2)) & -1677744 & $(1.05183)$ & {$[-1.59507]$} & 0.633440 & (1.18126) & {$[0.53624]$} \\
\hline $\mathrm{D}(\mathrm{KYD}(-1))$ & 0.011121 & $(0.00549)$ & [2.02423] & 0.003812 & $(0.00617)$ & [0.61788] \\
\hline $\mathrm{D}(\mathrm{KYD}(-2))$ & 0.007530 & $(0.00520)$ & [1.44933] & 0.003276 & $(0.00584)$ & {$[0.56146]$} \\
\hline $\mathrm{D}(\mathrm{JUB}(-1))$ & 0.000941 & $(0.00361)$ & {$[0.26063]$} & -0.010947 & $(0.00405)$ & {$[-2.70097]$} \\
\hline $\mathrm{D}(\mathrm{JUB}(-2))$ & 0.002819 & $(0.00394)$ & {$[0.71620]$} & -0.001456 & $(0.00442)$ & {$[-0.32946]$} \\
\hline $\mathrm{D}(\mathrm{LPE}(-1))$ & 0.494157 & $(0.18069)$ & [2.73485] & 0.109693 & $(0.20292)$ & {$[0.54056]$} \\
\hline $\mathrm{D}(\mathrm{LPE}(-2))$ & 0.312931 & $(0.21990)$ & [1.42303] & -0.734410 & $(0.24697)$ & {$[-2.97374]$} \\
\hline
\end{tabular}




\begin{tabular}{|c|c|c|c|}
\hline Cointegrating Eq: & CointEq1 & Cointegrating Eq: & CointEq1 \\
\hline $\operatorname{INF}(-1)$ & 1.000000 & $\operatorname{LPE}(-1)$ & 1.000000 \\
\hline $\operatorname{BIRATE}(-1)$ & $\begin{array}{r}-1.979897 \\
(1.40101) \\
{[-1.41319]}\end{array}$ & BIRATE(-1) & $\begin{array}{r}-0.532934 \\
(0.41864) \\
{[-1.27300]}\end{array}$ \\
\hline RSBI(-1) & $\begin{array}{r}-6.101992 \\
(1.75751) \\
{[-3.47195]}\end{array}$ & RSBI(-1) & $\begin{array}{r}-1.642490 \\
(0.48827) \\
{[-3.36390]}\end{array}$ \\
\hline RPUAB(-1) & $\begin{array}{l}5.304537 \\
(2.10294) \\
{[2.52243]}\end{array}$ & RPUAB(-1) & $\begin{array}{r}1.427836 \\
(0.58522) \\
{[2.43985]}\end{array}$ \\
\hline RKREDIT(-1) & $\begin{array}{c}0.122637 \\
(1.07902) \\
{[0.11366]}\end{array}$ & RKREDIT(-1) & $\begin{array}{r}0.033010 \\
(0.29561) \\
{[0.11167]}\end{array}$ \\
\hline $\mathrm{KYD}(-1)$ & $\begin{array}{r}-0.004288 \\
(0.00924) \\
{[-0.46420]}\end{array}$ & $\mathrm{KYD}(-1)$ & $\begin{array}{r}-0.001154 \\
(0.00245) \\
{[-0.47192]}\end{array}$ \\
\hline $\mathrm{JUB}(-1)$ & $\begin{array}{l}0.006127 \\
(0.00935) \\
{[0.65547]}\end{array}$ & $\operatorname{JUB}(-1)$ & $\begin{array}{c}0.001649 \\
(0.00247) \\
{[0.66737]}\end{array}$ \\
\hline $\operatorname{LPE}(-1)$ & $\begin{array}{l}3.715087 \\
(0.88192) \\
{[4.21248]}\end{array}$ & $\operatorname{INF}(-1)$ & $\begin{array}{c}0.269173 \\
(0.12288) \\
{[2.19047]}\end{array}$ \\
\hline
\end{tabular}

a. Model Inflasi

b. Model Output

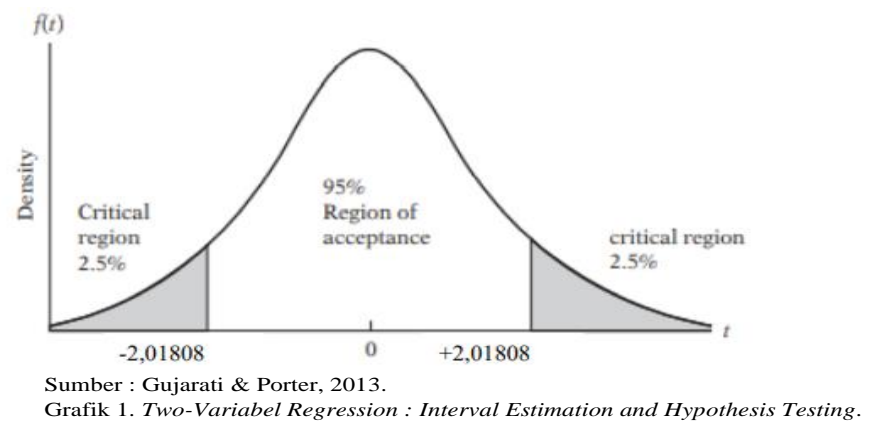

Gambar 1. Grafik Two-Variabel Regression: Interval Estimation and Hypothesis Testing

Jika mengacu pada uji t dan tabel t maka didapatkan hasil dari estimasi VECM, pada jangka pendek dalam model inflasi, penyaluran kredit yang disalurkan perbankan konvensional berpengaruh positif terhadap inflasi. Artinya, ketika terjadi kenaikan penyaluran kredit sebesar 1 simpangan baku/satuan pada kuartal sebelumnya, maka akan mengakibatkan peningkatan inflasi sebesar 1 satuan pada kuartal sekarang. Di sisi lain, pertumbuhan output berpengaruh positif terhadap inflasi dalam jangka pendek, yang berarti ketika terjadi kenaikan pertumbuhan output sebesar satu persen pada kuartal sebelumnya, maka akan mengakibatkan peningkatan inflasi sebesar satu persen pada kuartal sekarang. Sedangkan dalam model output, besaran moneter (JUB) memberikan pengaruh negatif pada jangka pendek terhadap output dalam pengertian menurunkan atau menahan pertumbuhan tingkat output. Hal ini menjadi dasar, mengapa pengendalian moneter melalui besaran moneter (based money) secara langsung berdampak terhadap inflasi yang tinggi (pada tahun krisis 1997-1998) sehingga merombak kerangka kebijakan moneter menjadi Inflation Targetting framework.

Sedangkan dalam jangka panjang, variabel suku bunga SBI (RSBI) memberikan dampak negatif terhadap Inflasi dalam pengertian menahan atau menurunkan inflasi. Namun, disaat bersamaan juga dapat menurunkan tingkat output dengan kata lain, RSBI memiliki pengaruh negatif terhadap output dalam jangka panjang namun juga terjadi penurunan output 
secara bersamaan. Begitu juga dengan variabel suku bunga PUAB, dalam jangka panjang memberikan pengaruh positif terhadap pertumbuhan output, tetapi diwaktu bersamaan memberikan pengaruh positif terhadap inflasi. Artinya, ketika terjadi kenaikan suku bunga PUAB sebesar satu satuan, maka akan mengakibatkan terjadinya kenaikan tingkat output namun diwaktu bersamaan diiringi oleh kenaikan inflasi.

\section{Kesimpulan}

Berdasarkan pembahasan dalam penelitian ini, peneliti menyimpulkan beberapa hasil penelitian sebagai berikut:

1. Secara kausalitas, tidak terdapat kesinambungan alur transmisi kebijakan moneter konvensional dengan inflasi dan pertumbuhan ekonomi.

2. Secara IRF, shock yang diberikan oleh variabel konvensional terhadap respon inflasi mereda dan stabil lebih lama. Dalam hal ini variabel konvensional bersifat inflationer.

3. Hasil varian dekomposisi menunjukkan, variabel kredit yang disalurkan oleh perbankan konvensional memiliki peranan penting dalam kontribusi positif terhadap output dibandingkan variabel lainnya. Akan tetapi, secara keseluruhan variabel konvensional memberikan kontribusi negatif yang lebih besar dibanding kontribusi positifnya.

4. Hasil estimasi VECM, dalam jangka pendek kredit yang disalurkan dan pertumbuhan ekonomi memberikan pengaruh positif terhadap inflasi (pemicu inflasi), sedangkan dalam jangka panjang, variabel RSBI memiliki pengaruh negatif terhadap inflasi namun saat bersamaan memiliki pengaruh negatif terhadap output. Namun, suku bunga PUAB memiliki pengaruh positif terhadap output tapi dalam waktu bersamaan memiliki pengaruh positif terhadap inflasi. Sehingga didapatkan bahwa variabel moneter konvensional tidak efektif dalam menurunkan inflasi maupun meningkatkan tingkat output.

5. Saran yang dapat diberikan baik untuk praktisi atau pengambil kebijakan yaitu agar dapat mengevaluasi kembali kinerja moneter konvensional dalam mencapai sasaran akhir. Penciptaan RSBI justru hanya akan menurunkan output dan penggunaan suku bunga PUAB justru hanya akan menciptakan inflasi. Meski kredit yang disalurkan memberikan kontribusi positif terhadap output tetapi masih lebih kecil dibandingkan kontribusi negatif yang diberikan oleh variabel konvensional lainnya. Oleh karenanya, memfokuskan penerapan kebijakan moneter dengan prinsip Syariah merupakan salah satu yang dapat sarankan dengan sistem bagi hasil dapat berpengaruh terhadap sektor rill maupun sektor keuangan. Melihat pada pengalaman krisis 1997-1998 dan 2008 serta hasil penelitian sebelumnya, bahwa variabel moneter syariah jauh lebih kuat terhadap krisis dan efektif dalam menaikkan tingkat output tanpa mengakibatkan kenaikan inflasi.

6. Bagi bagi peneliti selanjutnya disarankan dapat mencari lebih banyak referensi penelitian dan mengikuti perkembangan terkait kebijakan moneter konvensional yang tengah diterapkan oleh Bank Indonesia kedepannya serta variabel-variabel pendukung lainnya yang tidak dimasukan dalam penelitian ini (seperti GWM, Surat Berharga Negara). Peneliti kedepannya juga dapat melakukan perbandingan antara kebijakan moneter konvensional dan moneter Syariah dengan inflasi dan pertumbuhan ekonomi dengan menambahkan beberapa variabel Syariah di dalam penelitian agar didapatkan hasil perbandingan yang baik terkait kinerja kebijakan moneter konvensional dan moneter Syariah di Indonesia terhadap inflasi dan pertumbuhan ekonomi. 


\section{Daftar Pustaka}

[1] Ascarya, A. (2012). Alur Transmisi Dan Efektifitas Kebijakan Moneter Ganda Di Indonesia. Buletin Ekonomi Moneter Dan Perbankan, 14(3), 283-315. https://doi.org/10.21098/bemp.v14i3.360

[2] Kemu, S. Z., \& Ika, S. (2016). Transmisi BI Rate sebagai Instrumen untuk Mencapai Sasaran Kebijakan Moneter. Kajian Ekonomi Keuangan, 20(3), 261-284.

[3] Prabowo, B. P., \& Sihombing, P. (2019). Pengaruh Bi Rate, Suku Bunga Pasar Uang Antar Bank ( PUAB ) dan Faktor-Faktor Kinerja Bank. Jurnal Ilmiah Manajemen \& Bisnis, $3(1)$.

[4] Warjiyo, P. (2007). Stabilitas Sistem Perbankan Dan Kebijakan Moneter : Keterkaitan Dan Perkembangannya Di Indonesia. Buletin Ekonomi Moneter Dan Perbankan, 8(4), 429454. https://doi.org/10.21098/bemp.v8i4.144.

[5] Warjiyo, P., \& Zulverdi, D. (2003). Penggunaan Suku Bunga Sebagai Sasaran Operasional Kebijakan Moneter Di Indonesia. Buletin Ekonomi Moneter Dan Perbankan, 1(1), 2553. https://doi.org/10.21098/bemp.v1i1.159.

[6] Widodo, A. (2018). Evaluating the Effectiveness of Dual Monetary Policy in Promoting Price Stability in Indonesia. Iqtishadia, $10(2), \quad 210$. https://doi.org/10.21043/iqtishadia.v10i2.2378.

[7] Widodo, A. (2018). Evaluating the Effectiveness of Dual Monetary Policy in Promoting Price Stability in Indonesia. Iqtishadia, $10(2), \quad 210$. https://doi.org/10.21043/iqtishadia.v10i2.2378.

[8] Yudi Setiawan, R., \& Karsinah, K. (2018). Mekanisme Transmisi Kebijakan Moneter dalam Mempengaruhi Inflasi dan Pertumbuhan Ekonomi di Indonesia. Economics Development Analysis Journal, 5(4), 460-473. https://doi.org/10.15294/edaj.v5i4.22183.

[9] Zuhri, A. (2018). Analisis Kausalitas Antara Pertumbuhan Ekonomi, Inflasi, Jumlah Uang Beredar, Dan Sukuk Di Indonesia : Menggunakan Pendekatan Kointegrasi \& Kausalitas Granger. Program Magister Ekonomi Syariah Pascasarjana Universitas Islam Negeri Maulana Malik Ibrahim Malang, 53(9), 1689-1699 